Kaspars Balodis, Prof. Dr. iur.

University of Latvia, Latvia

\title{
THE DEVELOPMENT OF THE CONCEPT OF A COMMERCIAL TRANSACTION IN LATVIAN PRIVATE LAW
}

\section{KOMERCDARĪJUMU JĒDZIENA ATTİSTİBA LATVIJAS PRIVĀTTIESĪBĀS}

\begin{abstract}
Kopsavilkums
Latvijā komersantu (t. i., komercsabiedrību un individuālo komersantu) noslēgtos tiesiskos darījumus regulē Komerclikums. Šai jomā piemēro arī Civillikuma normas, ja Komerclikumā nav îpašu noteikumu. Komercdarijumu noteikumu galvenais mērḳis ir atvieglot darījumu noslēgšanu un nodrošināt šo darījumu ātru izpildi, taču vienlaikus Komerclikuma noteikumi par komercdarïjumiem ir stingrāki pret darījuma dalïbniekiem nekā Civillikumā ietvertās vispārīgās normas. Turklāt komercdarījumiem tiek piemēroti issāki noilguma termiṇi. Komerclikums kopumā balstās uz tā saukto subjektīvo sistēmu un parasti attiecas tikai uz komersantiem. Tādējādi komercdarijjumi ir komersanta tiesiskie darijumi, kas saistīti ar komercdarbību, bet tiesisks darījums uzskatāms par komercdarījumu tikai tad, ja tajā piedalās komersants. Turklāt šie darījumi ir saistîti ar komersanta komercdarbību. Tas nozīmē, ka komersanti, pastāvot zināmiem nosacījumiem, var būt privātu darījumu dalībnieki ārpus Komerclikuma darbïbas jomas. Pēc Komerclikuma komercdarījumu daḷas stāšanās spēkā 2010. gadā tiesas konsekventi piemēro Komerclikumā postulētos komercdarījumu noteikumus. Diemžēl dažos gadījumos novēroti mēǵinājumi ierobežot komercdarijjumu normu piemērojamību, interpretējot komersanta darijjumus kā tādus darījumus, kas nav komercdarījumi. Šì raksta mērḳis ir izskaidrot komercdarījumu jēdzienu Latvijas likumdošanā, argumentējot, ka komersants nekomerciālus (privātus) darījumus var noslēgt tikai izṇēmuma gadijjumos. Komerclikuma mērḳis ir nodrošināt, lai gandrīz visi komersantu veiktie darījumi ietilptu komercdarījumu regulējuma tvērumā. Ja komercdarījumu regulējuma piemērošanas joma tiktu ierobežota, tas nozīmētu, ka komersantiem būtu tiesỉbas uz īpašas labvēlības režīmu, ko nodrošinātu Civillikuma normas. Tas, iespējams, varētu apdraudēt komersantu noslēgto līgumsaistỉbu izpildi.
\end{abstract}

Atslēgvārdi: Latvijas Komerclikums, juridiskie darījumi, komercdarījuma jēdziens

\section{Summary}

In Latvia, legal transactions entered into by merchants (i.e. commercial companies and individual merchants) are governed by the Commercial Law. The general rules of the Civil Law also apply, as far as no special rules are contained in the Commercial Law. Generally, the aim of the provisions on commercial transactions is to facilitate conclusion of business transactions and to ensure a speedy fulfilment of these transactions. At the same time, the rules of the Commercial Law concerning commercial transactions are stricter than the general transaction rules of the Civil Law. Among other things, shorter terms of limitation are applied to commercial transactions. The Commercial Law as a whole is based on the so-called subjective system and generally applies only to those who are merchants. Accordingly, commercial transactions are legal transactions of a merchant 
which are connected with commercial activity. Thus, a legal transaction is considered commercial transaction only if a merchant is participating. Moreover, these transactions shall be related to merchants' commercial activity. This means that merchants, under certain conditions, can be party to private transactions. These are exempted from the scope of the Commercial Law. After entering into force in 2010, the provisions of commercial transactions part of the Commercial Law have been consistently applied by the courts. Unfortunately, in some cases there have been attempts to restrict the applicability of the provisions on commercial transactions by interpreting merchant's transactions as non-commercial transactions. The aim of this paper is to properly explain the concept of commercial transactions in Latvian law, arguing that a merchant can conclude noncommercial (private) transactions only in exceptional cases. The purpose of the Commercial Law is to ensure that almost all transactions concluded by merchants fall within the legal provisions on commercial transactions. If the scope of the concept of commercial transactions is restricted, merchants would be entitled to a preferential treatment under the general rules of the Civil Law. This could possibly endanger fulfilment of contractual obligations entered into by merchants.

Keywords: Commercial Law of Latvia, legal transactions, the concept of a commercial transaction

\section{Introduction}

According to Article 388 of the Commercial Law of Latvia ${ }^{1}$, commercial transactions are legal transactions of a merchant which are related to commercial activity. This means, firstly, that any commercial transaction is a legal transaction. The general definition of a legal transaction is provided by the Civil Law ${ }^{2}$. Secondly, only a transaction concluded by a merchant can have a status of a commercial transaction. According to Article 1, paragraph 1 of the Commercial Law a merchant is a natural person (individual merchant) or a commercial company (partnership and capital company) registered with the Commercial Register. In the third place, the merchant's transaction must be related to commercial activity. As defined in Article 1, paragraph 2 of the Commercial Law, commercial activity is an open economic activity, which is performed by merchants in their name for the purposes of gaining a profit. Thus, the concept of a commercial transaction, as defined in the Commercial Law, is seemingly simple. However, the words "related to commercial activity" mean that a merchant can also have private non-commercial transactions. These transactions would be exempted from the regulatory framework of the Commercial Law. The general rules of the Civil Law would apply in such case. The norms of the Civil Law are applied to any participant of civil legal relationships. On the one hand, the rules of Commercial Law are beneficial to a merchant by speeding up fulfilment of a contract. On the other hand, the provisions of Commercial Law, in comparison with the Civil Law, are stricter towards those who do not fulfil their obligations or do not claim their rights on time. The question is whether and how far a merchant can be treated as every other participant of civil law relationships. Therefore, the concept of a commercial transaction deserves a closer look in order to be correctly explained.

1 Komerclikums (The Commercial Law). Available at: https://likumi.lv/ta/en/id/5490-thecommercial-law [last viewed May 6, 2019].

2 Civillikums (The Civil Law). 12. izdevums. Rīga: Latvijas Vēstnesis, 2017. 


\section{Merchants' legal transactions according to the Commercial Law}

Article 388 of the Commercial Law refers to "legal transactions of a merchant". a transaction is considered to be commercial transaction, if at least one party is a merchant (Article 389 of the Commercial Law). In the latter case, the legal provisions on commercial transactions would apply only to the party who is a merchant. As an integral part of the private law system of Latvia, the Commercial Law is closely connected to the Civil Law. The latter forms the basis of the private law system in the country. Accordingly, the provisions of the Commercial Law on commercial transactions are special norms in relation to the Civil Law. They modify and supplement the regulation of the Civil Law with respect to merchants. The concept of a legal transaction is defined in the Civil Law. According to the Article 1401 of the Civil Law, a legal transaction is a lawfully performed action to establish, change or terminate legal relations. For example, any contract is legal transaction. There can also be unilateral legal transactions such as an issue of a power of attorney or a unilateral termination of a contract. According to Article 1428, paragraph 1 of the Civil Law, part of the essence of a legal transaction is the expression of intent by the transactor, but a bilateral or multilateral transaction requires a coherent expression of intent by all the parties. Thus, expression of intent is an essential element of any transaction. Legal relationships that are established without an expression of intent, such as obligation rights arising from tort or pursuant to law, are not "legal transactions" in the sense of the Civil Law.

Recently, there has been a scholarly discussion in Latvia whether the commercial transactions' three-year term of limitation (Article 406 of the Commercial Law) can be applied to merchant's obligations arising directly from law. ${ }^{3}$ In Latvia, many land plots and buildings thereon are owned by different owners, as a result of the land reform implemented after the restoration of country's independence. Property rights in land were restored to lawful owners or their heirs, whereas apartment buildings built on that land during the Soviet occupation where privatised to the tenants. To arrange the relationship between land and building owners, the so-called "compulsory lease" was introduced by law in the 1990s, obliging the apartment owners to pay lease to the land owners. ${ }^{4}$ Subsequently, a number of land plots beneath those apartment buildings were sold by the owners to commercial companies. Latvian courts have described the compulsory lease as an obligation arising from law. ${ }^{5}$ In such case the question arises whether a merchant who owns land beneath an apartment building can claim lease debts older than three years. The general term of limitation under Article 1895 of the

See: Snipe A. Par saistības un prasības noilgumu saistībai, kas radusies uz likuma pamata (On the Term of Limitation of an Obligation and Claim Arising from Law). Jurista Vārds, 26.09.2017., No. 40 (994); Kārklinš̌ J. Noilgums piespiedu nomas attiecībās komerctiesībās (The Term of Limitation in the Relationships of Compulsory Lease under Commercial Law). Jurista Vārds, 27.02.2018., No. 9 (1015).

4 See: likuma "Par zemes reformu Latvijas Republikas pilsētās" 12. pants (Article 12 of the Law on Land Reform in the Cities of the Republic of Latvia). Latvijas Republikas Augstākās Padomes un Valdỉbas Ziņotājs, 49/50, 19.12.1991.

5 Latvijas Republikas Augstākās tiesas Civillietu departamenta 16.09.2016. spriedums SKC193/2016 (Judgment of the Civil Department of the Supreme Court of the Republic of Latvia from 16.09.2016., SKC193/2016). Available at: http://www.at.gov.lv/lv/judikatura/judikaturas-nolemumu-arhivs/ civillietu-departaments/hronologiska-seciba?year=2016 [last viewed May 7, 2019]. 
Civil Law is ten years. At least in one case, the Supreme Court of Latvia stated that a compulsory lease relationship arising from law cannot be qualified as a commercial transaction. ${ }^{6}$ If such approach is continued, merchants would be entitled to preferential treatment contrary to the purpose of the regulatory framework of the Commercial Law. Recently, however, the Supreme Court (Senate) stated in another judgment that, considering the special circumstances of the case, the compulsory lease relations of the parties were a commercial transaction, and, consequently, the three-year limitation term of the Article 406 of the Commercial Law applied. ${ }^{7}$ It remains to be seen which trend will prevail in the jurisprudence of the Supreme Court.

The commercial transactions part of the Commercial Law is closely modelled after the commercial transaction rules of the German Commercial Code (Handelsgesetzbuch, HGB $).{ }^{8}$ According to $\$ 343$ of the HGB commercial transactions are all transactions of a merchant belonging to the operation of their commercial enterprise. In German commercial law, the concept of a merchant's transaction (Geschäft des Kaufmanns) is understood in a broader sense and includes any intentional actions of a merchant within his or her business activities. ${ }^{9}$ The concept of merchant's transaction in the sense of the HGB is broader than the general civil law concept of a transaction. ${ }^{10}$ Similar approach can be applied to the concept of "legal transactions of a merchant" used in Article 388 of the Commercial Law of Latvia. The scope of a legal transaction of a merchant in Latvian commercial law is broader than the usual concept of legal transaction of the Civil Law. This broad approach already has been supported in Latvian legal literature, by stating that merchants' legal transactions in the sense of Article 388 of the Commercial Law included any actions or dealings creating rights of claim and aimed at gaining economic benefit. ${ }^{11}$ The concept of legal transactions of merchants under the Article 388 of the Commercial Law shall include any legal relationships intentionally entered into by a merchant in the field of private law, except torts which are unlawful acts. For example, a benevolent intervention of a merchant in another's affairs (Article 2325 of the Civil Law) should be subject to the Commercial Law rules on commercial transactions.

6 Latvijas Republikas Augstākās tiesas Civillietu departamenta 16.03.2016. spriedums SKC-40/2016 (Judgment of the Civil Department of the Supreme Court of the Republic of Latvia from 16.03.2016. SKC-40/2016). Available at: https://manas.tiesas.lv/eTiesasMvc/lv/nolemumi [last viewed May 7, 2019].

7 Latvijas Republikas Senāta Civillietu departamenta 30.05.2019. spriedums SCK-104/2019 (Judgment of the Civil Department of the Senate of the Republic of Latvia from 30.05.2019. SKC104/2019. Available at: http://www.at.gov.lv/lv/judikatura/judikaturas-nolemumu-arhivs/civillietudepartaments/hronologiska-seciba?year=2019 [last viewed July 1, 2019].

8 See: Koncepcijas "Par komercdarijumu tiesisko regulejumu" kopsavilkums/The Summary of the Conception of the Legal Regulation of Commercial Transactions. Ministru kabineta 2005. gada 16. novembra rikojums Nr. 731/The Decree No. 731 of the Cabinet of Ministers from 16 November 2005. Latvijas Vēstnesis (Official Publisher of the Republic of Latvia), No. 184 (3342), 17.11.2005.

9 Lettl T. Handelsrecht. 4. Aufl. München: C. H. Beck, 2018, S. 197.

10 See: Klappstein V., $\mathbb{S} 343$ HGB Rn. 3. In: Heidel Th., Schall A. (Hrsg.) Handelsgesetzbuch: Handkommentar. Baden-Baden: Nomos Verlagsgesellschaft, 2011, S. 2147.

11 Kārklinš̌ J. Noilgums piespiedu nomas attiecībās komerctiesībās (The Term of Limitation in the Relationships of Compulsory Lease under Commercial Law). Jurista Vārds, 27.02.2018, No. 9 (1015). 


\section{Transactions related to merchant's commercial activity}

Considering the Commercial Law as whole, the rules on commercial transactions are based on the so-called subjective system. ${ }^{12}$ Namely, a merchant is subject to the provisions of the Commercial Law. However, there are few objective elements in the system of the Commercial Law. According to the Article 388 of the Commercial Law, only the transactions of a merchant that are related to commercial activity can be considered commercial transactions. The words "related to commercial activity", however, mean that objective criterions, too, have to be applied in order to identify commercial transactions. a link between a particular transaction and the commercial activity can be ascertained only from an objective viewpoint.

Depending on the closeness of a particular transaction to commercial activity, the commercial transactions are 1) key transactions, 2) auxiliary transactions or 3) sideline transactions. ${ }^{13}$ This classification of commercial transactions originates in German law and was acknowledged in Latvia already during the country's independence in the interwar period (1918-1940). ${ }^{14}$ The key transactions are the transactions typical for the regular commercial activity of the merchant. For example, an owner of a grocery store buys foodstuffs from his suppliers. Auxiliary transactions have an aiding function and are entered into with a purpose of starting, ensuring or terminating a commercial activity. For example, lease of office space, purchase of a cash register for the merchant's store or sale of merchant's enterprise. Sideline transactions are rather incidentally and are only indirectly related to the commercial activity of a merchant. Sideline transactions are not usual in the particular branch of business. ${ }^{15}$ For example, a publishing house sells a car belonging to this commercial entity. The broad notion of transactions related to commercial activity means that only very few transactions concluded by a merchant can remain outside the scope of commercial law rules. The very fact that the meaning of merchant's existence is to engage in commercial activity minimises the possibility of "non-commercial" transactions of a merchant.

\section{Private transactions of a merchant?}

As explained above, the reference to "legal transactions related to commercial activity" included in Article 388 of the Commercial Law implies that a merchant can have non-commercial transactions, too. The provisions of the Commercial Law would

12 Balodis K. The Development of and Prospects for Commercial Law in Latvia since Accession to the European Union. Journal of the University of Latvia "Juridiskā zinātne / Law", No. 5, 2013, p. 141. Available at: https://www.journaloftheuniversityoflatvialaw.lu.lv/fileadmin/user_upload/lu_portal/ projekti/journaloftheuniversityoflatvialaw/No5/5.Kaspars_Balodis.pdf [last viewed May 8, 2019].

13 Balodis K. Komercdarījumu vispārīgo noteikumu vieta un loma Latvijas privāttiesību sistēmā (The Role and Place of the General Provisions on Commercial Transactions within the Private Law System of Latvia). In: Komerctiesību aktuālie jautājumi Latvijā un Eiropā: Komercdarījumi. Atbildiba. Komercstrīdi (The Topical Problems of Commercial Law in Latvia and Europe: Commercial Transactions. Liability. Commercial Disputes). Riga: Tiesu namu aǵentūra, 2013, p. 62.

14 Zwingmann O. Lehrbuch des Handelsrechts. Riga: Verlag der Akt.-Ges. “Ernst Plates”, 1939, S. 331.

15 Lettl T. Handelsrecht. 4. Aufl. München: C. H. Beck, 2018, S. 199. 
not apply to such transactions. In order to ascertain, which transactions can be considered as non-commercial, the provisions of the Commercial Law need to be analysed. Article 390, paragraph 1 of the Commercial Law states: "In case of doubt a transaction of an individual merchant shall be deemed a commercial transaction. Within the meaning of this Article, making the record in accounting, input tax deduction, use of benefits obtained as a result of the transaction in commercial activity, etc., shall be considered as a link of the transaction to commercial activity”. According to Article 74 of the Commercial Law, an individual merchant is a natural person who is registered as a merchant with the Commercial Register. The main purpose of this provision is to ensure legal certainty in the field of commerce. ${ }^{16}$ Namely, an individual merchant shall not have an opportunity for avoiding the application of the Commercial Law, if a transaction is in fact related to his or her commercial activity.

Article 390, paragraph 1 of the Commercial Law applies only to individual merchants, not to commercial companies. This rule means that only individual merchants can enter transactions that are not commercial transactions. Namely, as natural persons they can conclude contracts and enter any other legal transactions outside their commercial activity. For example, they can buy a car for private use, rent an apartment to live in, marry or make a will. Such legal transactions are private transactions of an individual merchant. On the contrary, commercial companies cannot enter private transactions, their transactions always are commercial transactions. ${ }^{17}$ No commercial company can have a "private life". ${ }^{18}$ Of course, in some cases commercial companies conclude contracts that are not directly connected with their usual commercial activity. For example, a company buys a birthday gift for an employee or makes a donation to a charity. Nevertheless, these will be commercial transactions of that company under the category of "sideline transactions". A conclusion can be made that, within the meaning of Article 388 of the Commercial Law, a commercial company can have only transactions related to commercial activity.

\section{Conclusions}

Article 388 of the Commercial Law of Latvia defines commercial transactions as merchant's legal transactions related to commercial activity. The regulatory framework of commercial transactions is aimed at facilitating and speeding up conclusion and fulfilment of business transactions entered into by merchants. Generally, a merchant cannot be exempted from the regulatory framework of the commercial transactions part of the Commercial Law.

The notion of "legal transactions of a merchant" mentioned in Article 388 of the Commercial Law has to be interpreted broadly. a merchant's transaction in the sense

\footnotetext{
Balodis K., p. 62.

Lettl T. Handelsrecht. 4. Aufl. München: C. H. Beck, 2018, S. 199.

8 Klappstein V., $\ 343$ HGB Rn. 8. In: Heidel Th., Schall A. (Hrsg.) Handelsgesetzbuch: Handkommentar. Baden-Baden: Nomos Verlagsgesellschaft, 2011, S. 2148; Canaris C-W. Handelsrecht. 24. Aufl., München: C. H. Beck’sche Verlagsbuchhandlung, 2006, S. 331.
} 
of the Commercial Law is much more comprehensive than the general definition of a legal transaction commonly known from the Article 1403 of the Civil Law. With a few notable exceptions such as torts, the notion of legal transactions of a merchant shall include all legal relationships in the field of private a merchant has entered into by intent. That includes, inter alia, obligation rights arising from the law such as benevolent intervention in another's affairs or claims of unjust enrichment. The compulsory lease relationships common in Latvia and explained above shall also be commercial transactions, whether or not they are considered to be contractual relationships or obligations arising from law.

Furthermore, only an individual merchant as a natural person can be a party to transactions that are non-commercial or private. Due to their legal nature, commercial companies, such as partnerships, limited partnerships, limited liability companies and stock companies cannot be party to any private transactions. Since commercial companies do not have a "private life", all of their transactions are related to commercial activity. Any transaction entered into by a commercial company will be automatically considered as commercial transaction under the Commercial Law of Latvia.

\section{BIBLIOGRAPHY}

\section{Literature}

1. Balodis K. The Development of and Prospects for Commercial Law in Latvia since Accession to the European Union. Journal of the University of Latvia "Juridiskā zinātne / Law", No. 5, 2013, pp. 137-149. Available at: https://www.journaloftheuniversityoflatvialaw.lu.lv/fileadmin/ user_upload/lu_portal/projekti/journaloftheuniversityoflatvialaw/No5/5.Kaspars_Balodis. pdf [last viewed May 8, 2019].

2. Balodis K. Komercdarījumu vispārīgo noteikumu vieta un loma Latvijas privāttiesību sistēmā (The Role and Place of the General Provisions on Commercial Transactions within the Private Law System of Latvia). In: Komerctiesību aktuālie jautājumi Latvijā un Eiropā: Komercdarijumi. Atbildiba. Komercstrīdi (The Topical Problems of Commercial Law in Latvia and Europe: Commercial Transactions. Liability. Commercial Disputes). Rìga: Tiesu namu aǵentūra, 2013, pp. 59-76.

3. Canaris C-W. Handelsrecht. 24. Aufl., München: C. H. Beck'sche Verlagsbuchhandlung, 2006.

4. Heidel Th., Schall A. (Hrsg.) Handelsgesetzbuch: Handkommentar. Baden-Baden: Nomos Verlagsgesellschaft, 2011.

5. Kārkliņš J. Noilgums piespiedu nomas attiecībās komerctiesībās (The Term of Limitation in the Relationships of Compulsory Lease under Commercial Law). Jurista Vārds, 27.02.2018, No. 9 (1015).

6. Lettl T. Handelsrecht. 4. Aufl. München: C. H. Beck, 2018.

7. Snipe A. Par saistības un prasības noilgumu saistībai, kas radusies uz likuma pamata (On the Term of Limitation of an Obligation and Claim Arising from Law). Jurista Vārds, 26.09.2017. No. 40 (994).

8. Zwingmann O. Lehrbuch des Handelsrechts. Riga: Verlag der Akt.-Ges. “Ernst Plates”, 1939. 


\section{Normative acts}

9. Civillikums (The Civil Law). 12. izdevums. Rīga: Latvijas Vēstnesis, 2017.

10. Komerclikums (The Commercial Law). Available at: https://likumi.lv/ta/en/id/5490-thecommercial-law [last viewed May 6, 2019].

11. Likums "Par zemes reformu Latvijas Republikas pilsētās" (The Law on Land Reform in the Cities of the Republic of Latvia). Latvijas Republikas Augstākās Padomes un Valdības Ziṇotājs, 49/50, 19.12.1991.

\section{Court practice}

12. Latvijas Republikas Augstākās tiesas Civillietu departamenta 16.09.2016. spriedums SKC193/2016 (Judgment of the Civil Department of the Supreme Court of the Republic of Latvia from 16.09.2017, SKC193/2016). Available at: http://www.at.gov.lv/lv/judikatura/ judikaturas-nolemumu-arhivs/civillietu-departaments/hronologiska-seciba?year=2016 [last viewed May 7, 2019].

13. Latvijas Republikas Augstākās tiesas Civillietu departamenta 16.03.2016. spriedums SKC40/2016 (Judgment of the Civil Department of the Supreme Court of the Republic of Latvia from 16.03.2016, SKC-40/2016). Available at: https://manas.tiesas.lv/eTiesasMvc/lv/nolemumi [last viewed May 7, 2019].

14. Latvijas Republikas Senāta Civillietu departamenta 30.05.2019. spriedums SCK-104/2019 (Judgment of the Civil Department of the Senate of the Republic of Latvia from 30.05.2019, SKC-104/2019. Available at: http://www.at.gov.lv/lv/judikatura/judikaturas-nolemumuarhivs/civillietu-departaments/hronologiska-seciba?year=2019 [last viewed July 1, 2019].

\section{Other sources}

15. Koncepcijas "Par komercdarījumu tiesisko regulējumu" kopsavilkums (The Summary of the Conception of the Legal Regulation of Commercial Transactions. Ministru kabineta 2005. gada 16. novembra rikojums Nr. 731/The Decree No. 731 of the Cabinet of Ministers from 16 November 2005). Latvijas Vēstnesis (Official Publisher of the Republic of Latvia), No. 184 (3342), 17.11.2005. 